\title{
Resources and capabilities that determine the competitive success of a shoe company in Ticul, Yucatán
}

\section{Recursos y capacidades determinantes del éxito competitivo de una empresa de calzado en Ticul, Yucatán}

\author{
CARRILLO-CÁMARA, Adriana del Rosarioł*, MORALES-GONZÁLEZ, María Antonia and \\ CANTO-ESQUIVEL, Ana María
}

Instituto Tecnológico de Mérida / Tecnológico Nacional de México. Mérida, Yucatán, México.

ID $1^{\text {st }}$ Author: Adriana del Rosario, Carrillo-Cámara / ORC ID: 0000-0002-7318-9313, CVU CONACYT ID: 850664

ID $1^{\text {st }}$ Coauthor: María Antonia, Morales-González / ORC ID: 0000-0002-2637-0873, CVU CONACYT ID: 249534

ID $2^{\text {nd }}$ Coauthor: Ana María, Canto-Esquivel / ORC ID: 0000-0002-0068-6802, CVU CONACYT ID: 123485

DOI: $10.35429 / J B S .2019 .15 .5 .18 .25$

Received May 22, 2019; Accepted June 30, 2019

\begin{abstract}
The objective of this research is to study the economic activity of footwear at the business level of the municipality of Ticul, Yucatan, Mexico; It focuses on analyzing what resources and capabilities a shoe manufacturer company has with several years of operation in that municipality to remain in a highly competitive market. The research methodology is a case study of qualitative and descriptive scope in which resources and capacities are considered as categories of analysis. The results obtained indicate that the tangible and human resources, as well as the managerial capacities of production, sales and distribution are what determine the competitive success of the company. These results are expected to contribute to improving the development of the Ticul footwear sector because it is one of the main producers and the economic units established have the potential to grow and become more competitive.
\end{abstract}

Resources, Capabilities, Competitive

\begin{abstract}
Resumen
La investigación tiene como objetivo estudiar la actividad económica del calzado a nivel empresarial del municipio de Ticul, Yucatán, México; el cual se enfoca en analizar con qué recursos y capacidades cuenta una empresa fabricante de calzado con varios años de operación en dicho municipio para permanecer en un mercado altamente competitivo. La metodología es un estudio de caso de corte cualitativo y con alcance descriptivo en el que se consideran como categorías de análisis los recursos y las capacidades. Los resultados obtenidos señalan que los recursos tangibles y humanos, así como las capacidades directivas de producción, ventas y distribución son los que determinan el éxito competitivo de la empresa. Se espera que estos resultados contribuyan a mejorar el desarrollo del sector calzado de Ticul debido a que es uno de los principales productores y las unidades económicas establecidas cuentan con el potencial para crecer y llegar a ser más competitivas.
\end{abstract}

Recursos, Capacidades, Competitividad

Citation: CARRILLO-CÁMARA, Adriana del Rosario, MORALES-GONZÁLEZ, María Antonia and CANTOESQUIVEL, Ana María. Resources and capabilities that determine the competitive success of a shoe company in Ticul, Yucatán. Journal of Business and SMEs. 2019. 5-15: 18-25.

\footnotetext{
*Correspondence to Author (email: adriana_130592@hotmail.com)

$\dagger$ Researcher contributing first author.
} 


\section{Introduction}

For a company to become competitive, it must have the ability to maintain sustainable advantages over its competition over time, to differentiate its products and services by delivering added value to its customers and to expand its market share, all this in order to improve its profitability (Lanzas, Guevara and Duque, 2011). This sustainable advantage is the competitive advantage that the company develops, the one that is necessary to differentiate itself from the competitors through a unique value offer that makes the company the most preferred for customers (Porter, 1991).

Some authors such as Barney and Zajac (1994), Fong (2005), Hill and Jones (2009) and Grant (2010), mention that the competitive advantage is based on the theory of resources and capabilities, which consists in the exploitation of resources and the identification of the capacities to coordinate said resources and apply them towards productive use.

For this era of globalization in the case of the manufacturing sector in Mexico, González et al. (2012) argue that the only viable development strategy for the nation is an indiscriminate commercial opening where the country's economic authorities promote the idea that it is necessary to increase the competitiveness of companies. In this work, the research focused on the manufacture of footwear, being one of the branches that is within the manufacturing sector.

The National Chamber of the Footwear Industry (CANAICAL, 2016) mentions that Mexico has 8,225 productive units where $67 \%$ is located in Guanajuato, 20\% Jalisco and $13 \%$ in the Federal District, State of Mexico, Yucatán, Michoacán and Puebla. Currently, Yucatán has 341 economic units (EU) that practice this activity and develops mainly in the municipalities of Ticul, Hunucmá, Mérida, Valladolid and Chapab (INEGI, 2017). Ticul, is the main producer of footwear, of the almost 40 thousand inhabitants that make up the population, $80 \%$ are directly and indirectly dedicated to the manufacture of footwear for both men and women.
Of the 341 EU established in Yucatán, $60 \%$ of them are concentrated in Ticul and offers more than 453 thousand pairs a year, employs more than one thousand people and is constituted as the traditional economic engine of the southern region of the entity, by what generates well-being in the families that are engaged in the activity (Mejía, 2013; Diario de Yucatán, 2017; INEGI, 2017). However, the footwear sector in that municipality has low productivity because it has artisanal processes and basic industrial equipment (Martín, Parra and Navarrete, 2015); raw materials at high prices because shoemakers buy individually and in small quantities, distribution channels are limited at the state level and have little penetration at the regional level; the administration is incipient, focused on the daily income of the company and not an administrative system that allows them to analyze the situation of the company and carry out strategic planning, some owners or managers have few managerial skills and, finally, human capital It is mostly made up of unskilled labor, they are artisans, they learn from the trade based on the experience they acquire while working in factories (Ríos, personal communication, 2017).

It is considered that many of the aforementioned problems can be improved by identifying the resources and capabilities that favor the competitiveness of companies and thus trigger the local footwear industry; For research purposes, it was determined to study the resources and capabilities that influence the competitiveness of a shoe manufacturing company in Ticul, Yucatán.

\section{Methodology}

The design of this research is a qualitative cut case study, which explores a shoe manufacturing company (the unit of analysis) through detailed and in-depth data collection, using various sources of information (observations, interviews, and documents and reports) and reports a description of the case and the categories related to the problem statement. In relation to temporality, this case study falls into what Hernández, Fernández and Baptista (2014b) call temporary, because it takes place over a non-prolonged period (one year or less). The information is obtained from the field work, through a stay carried out within the company. The research focuses on contributing to improve competitiveness.

CARRILLO-CÁMARA, Adriana del Rosario, MORALESGONZÁLEZ, María Antonia and CANTO-ESQUIVEL, Ana María. Resources and capabilities that determine the competitive success of a shoe company in Ticul, Yucatán. Journal of Business and SMEs. 2019. 
Being a qualitative and non-quantitative study, categories of analysis and non-variables are determined, since research with qualitative approaches "focuses on relevant concepts in accordance with the evolution of the study that focuses on learning from experiences and points of view of individuals, value processes and generate theories based on the perspectives of the participants" (Hernández, et al., 2014a, p. 361). The analysis categories are the resources and capabilities focused on the internal structure of the company, which were measured or evaluated based on the theory of resources and capabilities, using the models of Grant (2010), Thompson, et al. (2012) and Hill and Jones (2009). The tool for collecting the information is a semi-structured interview and they were validated individually by the members of the tutorial committee, who are experts in the area and assigned by the Technological Institute of Mérida. In addition, pilot tests were conducted to determine the reliability of these.

The shoe manufacturer called "Company" for confidentiality reasons, was chosen through a survey conducted among the inhabitants of Ticul, who expose the company as one of the main ones due to its permanence and growth, since, it has more than 50 years old and is one of the ones that offers the highest number of jobs in the municipality. The actors or subjects of study are those who make up the company and the information collection tool is applied to them. Then, for practical purposes, each subject of study was assigned a code in which everyone carries the initial "E" of the interviewee and in table 1 they are listed with their respective gender, the area they occupy and the years of seniority within of the company.

\begin{tabular}{|l|l|l|l|}
\hline \multicolumn{1}{|c}{ Position } & \multicolumn{1}{c}{ Gender } & \multicolumn{1}{c|}{$\begin{array}{c}\text { aears of } \\
\text { antiguaty }\end{array}$} \\
\hline Directorate General & Male & 30 & EDG \\
\hline Administration & Female & 20 & EAN \\
\hline $\begin{array}{l}\text { Administration } \\
\text { Assistance }\end{array}$ & Female & 30 & EAA \\
\hline $\begin{array}{l}\text { Production and } \\
\text { maintenance }\end{array}$ & Male & 12 & EPM \\
\hline Wholesale sales & Male & 11 & EVM \\
\hline Expo and fair sales & Male & 10 & EVE \\
\hline Counter sales & Female & 01 & EMR \\
\hline
\end{tabular}

Table 1 Coding of study subjects Source: Self Made
The interview guide has questions regarding the background and current situation of the company to know its overview and also to identify and analyze its resources and capabilities. The instrument is designed with four sections and the reagents are 46 to 74 in total, since they are formulated according to the level of each interviewee and the area / department in which he works. A general outline of the tool is presented in table 2 .

\begin{tabular}{|c|c|c|}
\hline Section & Item & Sub-item \\
\hline $\begin{array}{l}\text { Company } \\
\text { Background }\end{array}$ & --- & \\
\hline $\begin{array}{l}\text { Current } \\
\text { situation }\end{array}$ & -------- & -------- \\
\hline $\begin{array}{c}\text { Analysis } \\
\text { Category }\end{array}$ & Type & Indicator \\
\hline \multirow{9}{*}{ Resource } & \multirow{3}{*}{ Tangible } & $\begin{array}{l}\text { Machinery and } \\
\text { equipment }\end{array}$ \\
\hline & & Materials and supplies \\
\hline & & $\begin{array}{l}\text { Plant or factory, } \\
\text { facilities, } \\
\text { location and / or store. }\end{array}$ \\
\hline & \multirow{3}{*}{ Intangible } & Brand \\
\hline & & Reputation \\
\hline & & Technology \\
\hline & \multirow{3}{*}{ Human } & Organization \\
\hline & & Division of labour \\
\hline & & Personal knowledge \\
\hline \multirow{6}{*}{ Capacity } & \multirow{2}{*}{$\begin{array}{l}\text { Directorate } \\
\text { General }\end{array}$} & Academic training \\
\hline & & Leadership \\
\hline & $\begin{array}{l}\text { Development } \\
\text { and research }\end{array}$ & --- \\
\hline & Marketing & -------- \\
\hline & $\begin{array}{l}\text { Sales and } \\
\text { distribution }\end{array}$ & ------- \\
\hline & $\begin{array}{l}\text { Production } \\
\text { process }\end{array}$ & -------- \\
\hline
\end{tabular}

Table 2 General scheme of the semi-structured interview tool

Source: Self Made

For the processing and analysis of the information obtained, recordings were made with each informant, which were later transcribed with the support of the "Groove Music" audio program. The information was captured with their respective question in the Word program, later the phrases and / or words that coincided between the CEOs and the rest of the staff were compared and marked, and in the end those results were compiled in the same document to be analyzed. and interpret them. 


\section{Results and Discussion}

A company owning a competitive advantage means that it has been able to establish a strategy that has given it greater benefits than the average of the industry in which it operates (Fong, 2005); These extraordinary benefits are obtained when the rate of benefits produced by their resources and capabilities is higher than necessary (Barney, 1994 cited in Fong, 2005).

With the above, the "Company" has been considered as one of the most competitive within the Ticul footwear industry, so its resources and capabilities are determined in this section according to the information obtained from the interviewees and based to which Wernerfelt (1984) points out that a resource (capacity) is everything that could be considered a strength or weakness of a given company. In addition, its competitive advantage is measured based on the following questions proposed by Thompson, et al. (2012): Is the resource (or capacity) competitively speaking valuable? Is the resource infrequent, rivals lack it?; this in order to compare their resources and capabilities with respect to their competition.

\section{Company Background}

The "Company" manufacturer of footwear was founded in June 1960 by the father of the current $\mathrm{CEO}$, the main reason was the demand for footwear that was being lived at that time. The founder started the company through his own resources, obtained from several jobs as a saddle and waiter, his income was used for the purchase of machines and tools for the production of shoes, he had the habit of investing what he earned and it was how he managed to start the "Company A".

Currently, the company is requesting loans to finance its costs and expenses, "financing and credit are very important, it is essential because that capitalizes us to support production, payroll and suppliers, while the client pays us" mentions the EDG informant.
During the company's growth cycle, it has gone through two specific situations: the trade union movement led by Efraín Calderón the "Charras" in 1970, for which the footwear industry had a setback, as several owners of the Shoe stores had to pay their participation in the strike with machines and tools, the solution to this problem was through savings and currently it is operated, "the investment is our solution, you have to invest to update," says the informant EDG.

Another relevant situation is that when the general director enters the policy, the solution for this moment was to entrust the company completely to the administrator, wife of the general director, who is the one who makes the decisions of the company for several years.

\section{Current situation of the company}

The company is currently constituted as a legal entity and has 25 employees without counting the general manager and the administrator. The company's sales are divided into approximately $80 \%$ wholesalers and $20 \%$ retailers; wholesale customers are located in the southern states of the country such as Yucatán, Campeche, Quintana Roo, Chiapas, Oaxaca, Tabasco and Veracruz; in the case of retail customers they come from the same state as Mérida, Tizimín, Valladolid, Motul, and "once a month through excursions people come from far away," the informant EAN mentions. The delivery of orders to wholesale customers is done in two ways: through the driver that the company has and shipping centers such as Express MG.

The company is affiliated with CANACO SERVYTUR, which has received advice on sales and staff training. Although the company has participated in the talks offered within the chamber, this has not led to the owners having written mission, vision and business objectives, so they work as the situation occurs, however They are clear about their approach, which consists in the search for the "standard of good quality in the products, so that the clients leave satisfied, so we are constantly searching for modeling to satisfy all that is required with regard to fashion and design "(EDG). 
Finally, the senior managers believe that the company distinguishes itself from the competition by having a shoe termination system different from the others, since they continue to apply the old cleaning process "which is to paint selvedges, slice, paste, etc. , then the finish that others use is practically to pass the rag and fit the footwear "(EAN), the company tries to take care of the quality of the finish; also, they strive to update themselves and want to do things correctly with each style, for example, they use quality materials and good lasts that correspond to the shoe, and in addition to focusing on quality, they also do it in fashion and price. With the latter they try not to raise their sales costs, because most of the sales are to wholesale customers. In a matter of how the company's staff reacts to changes in the environment, in their entirety they affirmed that they are available for any change, since they are aware that it is part of the company's turn.

\section{Resources}

This section focuses on the resources that the company has, in figure 1 they are broken down into tangible, intangible resources and, subsequently, the analysis process of each one is carried out.

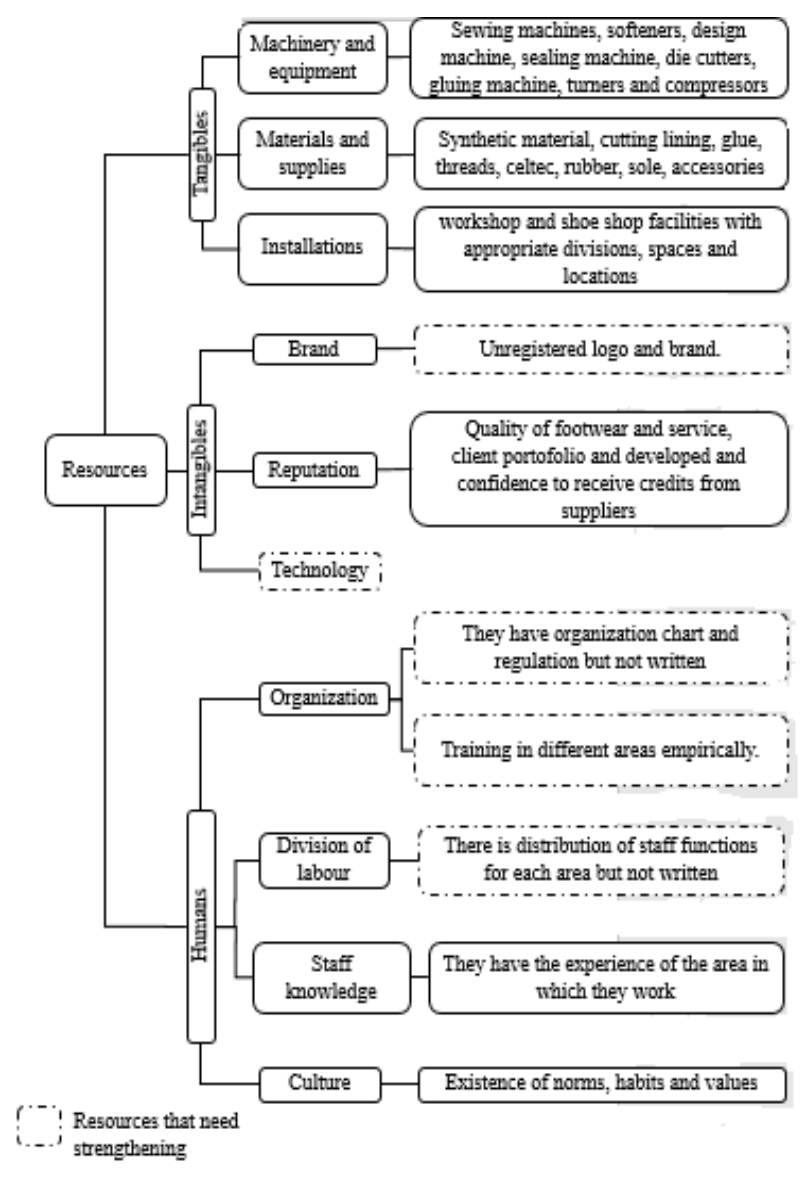

Figure 1 Resources of the "Company"

Source: Self Made

\section{Tangible Resources:}

Even though the company makes a semiartisanal production, it has the essential tangible resources to produce footwear: the machinery and equipment it has are not all of its competitors. The materials and supplies ensure that they are of quality and use some that they consider give more to your product. Facilities and areas of operation are well divided and distributed, as well as suitable locations for your factory and point of sale.

\section{Intangible Resources:}

The company needs to strengthen its brand, since the logo and the name of the company do not have the registration before the Mexican Institute of Industrial Property (IMPI), however, the name of the company, because it is the name of a city and probable use of it by another company makes the registration process difficult to carry out. On reputation, it is perceived as good since it is recognized by both its customers and its suppliers for several years. With regard to technology, it is a resource which the company needs to strengthen, since, currently, the company is considered lagging, however, it is contemplated to enter this area to maintain and improve its permanence in the market.

\section{Human Resources:}

The company has adequate human resources from the division of labor, knowledge of staff and organizational culture, however, in relation to the organization it is necessary to strengthen it because it does not have a written organization chart and regulation, despite that do have jobs described and established. Staff training is given empirically and not always constantly.

\section{Capacities}

This section presents the capabilities of the "Company". In figure 2, the general direction, production process, development and research, marketing, sales and distribution and finally finances are approached and then the analysis process of each one is carried out. 


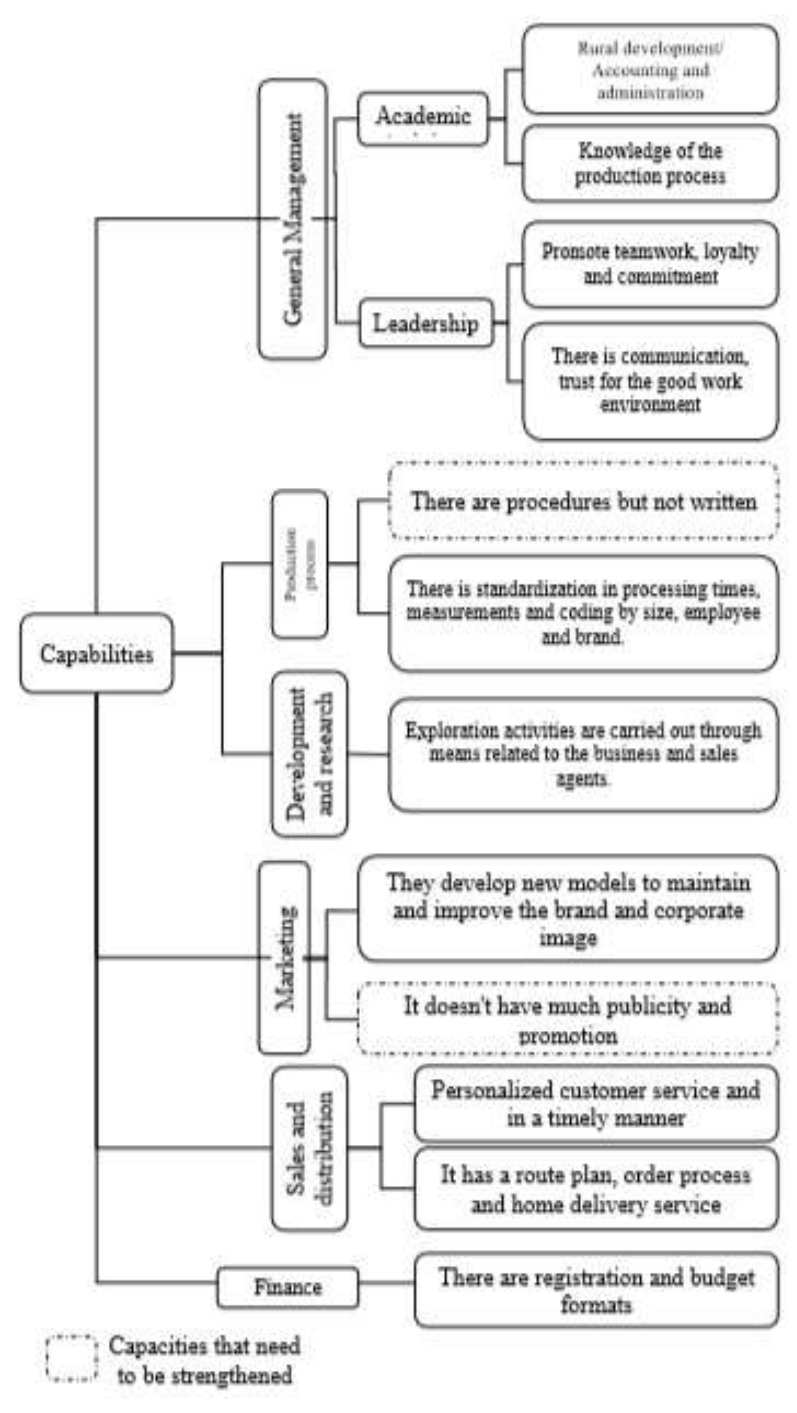

Figure 2 Capabilities of the "Company" Source: Self Made

\section{General Address:}

The company has certain capabilities that have allowed it to remain in the market for several years. Initially, the directors of the shoe manufacturing company have the appropriate academic training to manage it, as well as have a leadership that promotes teamwork, loyalty and commitment among the rest of the staff.

\section{Production process:}

This capacity should be strengthened since there is no written procedures manual, so that the company has become accustomed to working empirically, however, standardization processes have been established such as processing times, measurements and coding by size, employee and brand (either of the company or the wholesale customer).

\section{Development and research:}

The company conducts activities to explore fashion trends and customer needs through sources such as internet, specialized magazines and sales agents.

\section{Marketing:}

They develop new models to maintain and improve the image and brand of the company, however, the areas of advertising and image of the point of sale should be strengthened.

\section{Sales and distribution:}

Another important capacity that has been a competitive advantage for the company is its ability to carry out sales through personalized customer service in a timely manner, as well as in the distribution of footwear for wholesale customers.

\section{Finance:}

The company's finances are reflected in registration formats, although this registration is carried out manually, it has not been a limitation for the company to manage all its expenses and costs.

\section{Conclusions}

The tangible resources of the company that are competitively valuable and rare:

Machinery and equipment. This has been indispensable to carry out the semihandmade production process of footwear, if to improve the production process other machinery or equipment is required, the company considers the acquisition of a new one.

Materials and supplies. All the materials and supplies that the footwear requires are used and always try to acquire the best quality and add accessories to give more to the footwear.

Installations. The factory and the point of sale have the appropriate facilities and area divisions that have allowed the members of the company to work in a more organized and efficient way. 
The company's intangible resources that are valuable competitively and infrequently:

Reputation. They try to take care of the quality of the footwear and the service that they offer to their clients, which influences them to have clients of several years; They have also obtained that the providers give them the confidence to grant them credits since they have kept a payment history in a timely manner. This resource has been essential for the company to remain up to date in the market and continue.

The company's human resources that are valuable competitively and infrequently:

Staff knowledge the staff has the knowledge and experience in the area that works because most of them for several years have been dedicated to the activity of making shoes. Culture. The work environment built by the members of the company has a positive influence on its competitive development.

The company's capabilities that are valuable competitively and infrequently:

\section{General direction}

The company is directed not only by the CEO but also by the administrator, who is the person with the full authorization for decision-making, both have degrees related to the turn of the company and the sectoral environment that surrounds them, and both They come from families dedicated to shoemaking. In addition to having the knowledge, both have leadership skills that have contributed to communication, trust, teamwork, loyalty and commitment.

\section{Development and research}

The activities of exploration through means related to the turn of the business and sales agents have been essential for the company to keep constantly updated regarding the trends of footwear models.

\section{Sales and distribution}

The personalized customer service has helped the company generate customers for several years and can also expand beyond the state of Yucatan. By having a route plan, order process and home delivery service allows order deliveries to arrive at their destination in a timely manner.

\section{Finance}

The company seeks to fully register all its expenses and costs to assign a fair sale price, which allows it a profitable profit to continue operating in the market.

\section{References}

Barney, J. B., y Zajac, E. J. (1994). Competitive Organizational Behavior: Toward an Organizationally-Based Theory of Competitive Advantage. Strategic Management Journal, 5-9.

Cámara Nacional de la Industria del Calzado (CANAICAL). (2014). Industria del Calzado en México. Recuperado de http://www.canaical.org/industria-delcalzado.html

Diario de Yucatán. (2017). Impulso a la producción de calzado en el sur yucateco. Recuperado http://yucatan.com.mx/merida/politicamerida/impulso-la-produccion-calzado-suryucateco

Fong, R. C. (2005). La teoría de los recursos y capacidades. Fundamentos microeconómicos. México: Universidad de Guadalajara.

González, M. M. L., Olmedo, C. B., Vázquez, L. R., Rueda, P. I., Portos, P. I., Sánchez, V. A., Bouchain, G. R., y González, A. A. L. (2012): Globalización y dinamismo manufacturero. México y otros países emergentes. UNAM Instituto de Investigaciones Económicas. Recuperado de http://biblioteca.clacso.edu.ar/gsdl/collect $/ \mathrm{mx} / \mathrm{m}$ x-030/index/assoc/D12820.dir/pdf_674.pdf

Grant, R. M. (2010). Contemporary Strategy Analysis. Spain: John Wiley and Sons Ltd.

Hernández, S. R., Fernández C. C., y Baptista, L. M. (2014a). Metodología de la Investigación. Mc Graw Hill.

Hernández, S. R., Fernández, C. C., y Baptista, L., P. (2014b). Estudio de casos. Material complementario: capítulos adicionales. En R. Hernández Sampieri, C. Fernández Collado, \& P. Baptista Lucio, Metodología de la Investigación, 1-31. México: McGrawHill.

Hill, C. W., y Jones, G. R. (2009). Administración Estratégica. México: McGraw Hill.

CARRILLO-CÁMARA, Adriana del Rosario, MORALESGONZÁLEZ, María Antonia and CANTO-ESQUIVEL, Ana María. Resources and capabilities that determine the competitive success of a shoe company in Ticul, Yucatán. Journal of Business and SMEs. 2019. 
Instituto Nacional de Estadísticas y Geografía (INEGI). (2017). Directorio Estadístico nacional de Unidades Económicas. Recuperado de

http://www.beta.inegi.org.mx/app/mapa/denue/ default.aspx

Lanzas, D. A. M., Guevara, J. Y. P., y Duque, V. C. J. (2011). Propuesta para potenciar la competitividad en las empresas de confecciones del AMCO a partir de las cinco disciplinas. Scientia et Technica, 59-64.

Martín, C. E. V., Parra, A. F. Y., y Navarrete, C. R. A. (2015). La industria del calzado de Ticul, un panorama hacia la competitividad. AMECIDER-CRIM, UNAM. Recuperado de http://ru.iiec.unam.mx/id/eprint/2975

Mejía, J. (2013, diciembre, 30). Época de bonanza para el sector zapatero en Yucatán. Milenio Novedades. Recuperado de https://sipse.com/milenio/epoca-de-bonanzapara-el-sector-zapatero-en-yucatan-68400.html

Porter, M. E. (1991). Ventaja competitiva. Creación y sostenimiento de un desempeño superior. Buenos Aires: Rei Argentina, S.A.

Suárez, H. J., e Ibarra, M. S. (2002). La teoría de los recursos y capacidades. Un enfoque actual en la estrategia empresarial. Anales de estudios económicos y empresariales, 63-89.

Thompson, A. A., Gamble, J. E., Peteraf, M. A., y Strickland, A. J. (2012). Administración estratégica. México: McGraw Hill.

Wernerfelt, B. (1984). A Resource-Based View of the Firm. Strategic Management Journal, 5, 171-180. 